\title{
The Existence of Financial Services Authority in Handling Illegal Financial Technology Companies
}

\author{
Sunaryo \\ \{sunaryo.fhunila@gmail.com\} \\ Faculty of Law, University of Lampung
}

\begin{abstract}
Financial technology (fintech) companies grow rapidly in Indonesia. Besides the existence of fintech which can help society in accessing financial products, it can also give the negative impacts that can harm society, for example is the high number of infringement complains towards illegal fintech companies. This status quo is not consentient with the aims of Law Number 21 of 2011 about Financial Services Authority (FSA) which focuses on sustainability and stability of financial services sector growth and protecting consumer and society's interest. The aim of this study is to fully elaborate the existence of FSA that contains FSA's duties, authorities, and obstacles in handling illegal fintech companies. The design of this study is an empiric normative law with a descriptive type and applied law approach. The result of this study shows that FSA has duty and function in organizing system setting and controlling financial services sector. FSA not only has authority to establish operational policy and administrative penalty for the companies who break laws, but also to prevent disadvantages, give service to the consumer's denunciation, and give law defense for consumer's behalf. The obstacles which face FSA in handling the existence of illegal fintech companies is coming from both internal and external side.
\end{abstract}

Keywords: authority; financial services authority; illegal fintech; obstacles

\section{Introduction}

Financial technology (fintech) companies grow rapidly in all around the world, including Indonesia. The existence of fintech aims to help society in accessing financial products easily, giving an ease transaction, and increasing financial literacy. Fintech is one of the startup world which focuses in maximize technology to change, accelerate, or improve many aspects of finance service. Finance service starts from payment method, fund transfer, loan, fundraising, up to asset management in the implementation of targeting society's interest in accessing credit online system in Indonesia. Related to fund service, in Article Number 1 paragraph (3) Law of Financial Services Authority Number 77/POJK.01/2016 of Fund Loan of Information Technology Based Service stated that fund loan of information technology service is a financial services as a bridge between fund donors and fund recipients in the term of loan agreement holding in rupiahs directly with electronic system by internet data.

Financial Service Authority (FSA) is a the highest authority holding institution and called extraordinary institution which means FSA have setup removal function and control towards financial institution. All financial business in Indonesia is under FSA's regulation and monitor which free from every interventions. One bad thing from the existence of super power 
institution can bring worries about its authority. The base of FSA formation is from amendment of Article 34 Law Number 3 of 2004 about Modification of Law Number 23 of 1999 about Bank Indonesia. According to Article 34, FSA is independent in the term of doing its job and its status is beyond the government also has obligation to deliver the report to The Audit Board of Indonesia and Parliament.3

The existence of FSA institution nowadays is important and needed, retrieving many illegal fintech companies which can harm consumers. Illegal fintech companies can be named because of its existence is not listed and do not have permission to run its business in the finance service sector from FSA. Refer to data from FSA Custodian that said there are 635 fintech companies which not registered yet. From these companies, the license of 231 fintech companies have closed by FSA due to these existence is not registered and do not have license from FSA based on Law of FSA Number 77/POJK.01/2016 which means it can potentially harm society. 4 The high number of illegal fintech shows that the existence of FSA institution is needed and has important role to protect society from the existence and activity of financial institution especially illegal fintech which spread and grow rapidly in Indonesia.

The fintech companies blooms and grows the popularity in Indonesia due to several reasons, there are:

1. Internet usage through smartphone spreads fast so online fund transaction is needed;

2. Fintech is considered more practical when it is compared to the rigid-conventional finance industry;

3. Digital technology based business grows;

4. Online finance industry as a simple method used by startup businessmen; and

5. Social media usage enable fintech industry grows due to the data which uploaded by user to social media can be used to society risk analysis. 5

Anikina et al. as quoted by Svetlana Saksonova and Irina Kuzmina-Merlino stated, there are two main reasons for the emergence of fintech companies. First, the global financial crisis of 2008, has vividly demonstrated to consumers the shortcomings of the traditional banking system that led to the crisis. Second, the emergence of new technologies that helped provide mobility, ease of use (visualization of information), speed and lower cost of financial services.

The accretion of fintech companies gives the advantages for businessmen who unaware of banking service as well. The development of fintech companies are expected to expand business in finance service sector. On the other hand, in the practical, there are a huge number of the existence of unregistered and licensed fintech by FSA and disobeying the Law of FSA. POJK Nomor 77/POJK.01/2016 had assigned that every finance companies need to register and has the license from FSA to ran their companies' programs. This law is not only aiming for legality from fintech companies which already need to have, but also aiming for protecting society from every shape of trespass which will cause disadvantages for consumer. Refer to those explanation, it shows that FSA is needed for the presentation of illegal fintech companies.

Based on those background, things that would be discussed are:

1. How is the task and authority of Financial Services Authority in handling and controlling implementation of fintech companies?

2. What are the obstacles that face Financial Services Authority in handling the existence of illegal fintech companies?

This study has aim to get exact, full, and systematic description of:

1. Task and authority of Financial Services Authority in handling and controlling implementation of fintech companies. 
2. Obstacles that face Financial Services Authority in handling the existence of illegal fintech companies.

The usage or benefit from this study is theoretical and practical purposes. Theoretically, this study is expected to increase the effort of jurisprudence, especially in the scope of economical law which related to the existence of FSA institution in handling and controlling financial institutions' activity in Indonesia. Practically, this study is expected to be a comprehensive information in studying financial institution law, especially for FSA related to its task, authority, and law construction for disobeyed companies. This study is also expected to be a suggestion in the term of getting improvement for a few slackness nowadays. At the end, this study is expected to be useful for company law's reference enrichment, especially for FSA which seemed to be helpful nowadays.

\section{Method}

The type of this study is an empiric-normative law study with descriptive type. The problem approach in this study is an applied law approach. An applied normative approach type is live case study, which means normative law provision applied for on-going or unfinished law occasion. The data in this study is coming from primary and secondary data's. The primary data are collected from interview, meanwhile the secondary data which is used in this study contains of primary and secondary law material.6 The data in this study is collected by interview and research library. After the data is collected, it is processed by the data selection, classification, and systematization, then qualitative analyzed by elaborating data to the complete, clean, detailed, and systematic sentence for getting answer about the problem so it can be concluded.

\section{Result and Discussion}

\subsection{Task and Authority Finance Service Authority in Handling and Controlling Fintech Company Implementation}

In Indonesia, finance service sector's development have important transformation along with the existence of Financial Service Authority (FSA) with Law Number 21 of 2011 about Financial Service Authority. Financial Service Authority is formed by the aims of all financial service activities in financial service sector can be done in order, fair, transparent, and accountable, also can create financial system which grows sustainable and stable and can protect consumer and society's interest. With all this aims, FSA is expected to support national financial service sector's interest and increase national competitiveness. Financial Service Authority need to protect national interest such as human resource, management, control, and ownership in financial service sector with considerate positive aspects of globalization.

Financial Service Authority is an institution in financial service which is free and independent from every party intervention. Related to the aim of this institution formed, FSA has an important position along with task and authority switchover which at the first owned by Bank Indonesia. In Law of FSA it is also regulate the relation between institution and its cooperation, retrieve at some significant problems towards this switchover. Related to the innovation of financial service that developed in the society, it feels important to know the 
basic rules. By looking at the development of regulation about financial technology service in Indonesia nowadays, there are two institution included, there are Bank Indonesia and FSA. The regulations related to fintech which coming from Bank Indonesia, such as:

1. Regulation of Bank Indonesia Number 18/40/PBI/2016 about Process of Payment Transaction.

2. Regulation of Bank Indonesia Number 19/12/PBI/2017 about Financial Technology.

3. Regulation of Member of Governors Number 19/14/PADG/2017 about Regulatory Sandbox of Financial Technology.

4. Regulation of Member of Governors Number 19/15/PADG/2017 about the Regulation of Registration, Information Delivery, and Financial Technology Controller.

Meanwhile the regulation made by FSA related to the innovation in financial service until nowadays is Regulation of FSA Nomor 77/POJK.01/2016 about Fund Loaning Information Technology Based Service. This regulation control things which have to obey by peer to peer landing business. It is expected to protect consumer interest related to fund and data security and national interest of prevention of fund and terrorism fund, and financial system stability. The consequence of that regulation is the provider of information technology based loan service need to register membership to FSA by providing escrow account and virtual account in banking and put center data in Indonesia as a condition. The existence is legal when it is already registered.

Related to Law of Bank Indonesia Number 19/12/PBI/2017 about Financial Technology Implementation said that financial technology is the usage of technology in financial system that produce products, services, technologies, and/or new business model and can give impact to moneter stability, financial system stability, and/or efficiency, continuity, security, and payment system reliability. Ones that included in financial technology category are financial system, market support, investation management, and risk, loan, financing, and modal provision management, also the other financial service.

The existence of FSA in financial service sector need to be done integrated, independent, and accountable. As an independent institution, FSA need to run the task and authority based on these aspects:

1. Independent aspect, the independency in decision making and run the function, task, and authority of FSA, by stick on the ongoing law;

2. Law certainty aspect, as a state law where prioritize law and justice in every FSA policy;

3. Public interest aspect, to stand up and protect consumer and society interest and increase welfare;

4. Clarity aspect, to give a explication towards society right to get true, fair, not discriminative information about FSA on the security of personal, group, and state secret rights, included the secret which is set in the law;

5. Professionalism aspect, this aspect prioritize the proficiency in doing task and authority of FSA with stick on code of ethical and law;

6. Integrity aspect, which strongly stick on the moral value in every action and decision towards FSA; and

7. Accountability aspect, to decide that every activity and final result from every FSA activities need to be accounted to public.

Independency aspect of FSA is stated in Article 2 Paragraph (2) in FSA law, that FSA is an independent institution in doing task and authority, free from the other intervention, except for points that strongly ruled in this law. Related to that task and authority, in Article 5 of FSA 
Law stated that FSA has function to organize integrated set up and control system toward all sector in financial service. The scope of set up and control task, such as:

1. financial service in banking sector;

2. financial service in capital market sector; and

3. financial service in assurance, pension fund, banking institution, and other financial service sector.

The set up task above is implemented by board of commissioners, by assigning FSA law, board of commissioners law, and/or board of commissioners decision. Financial Service Authority has some authority to success its institution aims. Related to the set up task in every financial services, so FSA has authority to:

1. assign this law implementation;

2. assign law in the financial service sector;

3. assign FSA law and decision;

4. assign the law of control in the financial service sector;

5. assign the policy of FSA task implementation;

6. assign the law of written law regulation towards financial service institution and other party;

7. assign the law of stature manager regulation in financial service institution;

8. assign organization and infrastructure structure and manage, maintain, and administer wealth and responsibility; and

9. assign the law of penalty regulation based on the law in financial service sector.

In the term of supervision task towards financial services activity, in Article 9, FSA is given the authority to:

1. assign supervision operational policy towards financial service activity;

2. super visioning the supervision task by head of executive;

3. carry out the supervision, checker, investigation, consumer safety, and other proceeding toward financial service institution, perpetrator, and/or financial service action supporter that referred in the law of financial service sector;

4. give written command to financial service institution and/or certain party;

5. appoint a statutory manager;

6. set the use of the statutory manager

7. establish administrative penalty against those who violate the laws and regulations in the financial services sector; and

8. give and/or revoke

a. permission of business;

b. permission of individuals;

c. effectiveness of the registration statement;

d. certificate of registered letter;

e. approval to conduct business activities;

f. endorsement;

g. approval or stipulation of dissolution; and

h. other stipulations, as referred to the law in the financial services sector.

The authority above provides a large role and influence for FSA in financial sector service activities including law enforcement efforts to protect consumers in financial services. In addition, in an effort to protect consumers, the FSA Law regulates the consumer and community protection. Several regulations and/or policies as a derivative of FSA Law that support the implementation of integrated consumer services, while strengthening the 
implementation of complaints and dispute handling through the Internal Dispute Resolution and Alternative Dispute Resolution mechanisms, such as:

1. FSA law Number 1/POJK.07/2013 about Consumer Protection in Financial Service Sector.

2. FSA law Number 1/POJK.07/2014 about Alternative Institution of dispute resolution in Financial Service Sector.

3. Board of Commissioner Law about LAPS in Financial Service Sector, such as:

a. Circular letter of FSA Number 2/SEOJK.07/2014 about Service and Settlement of Costumer's Complain Towards Financial Service Company.

b. Circular letter of FSA Number 7/SEOJK.07/2015 about Regulation of Alternative Institution Settle Scoring in Financial Service Sector.

c. Circular letter of FSA Number 54/SEOJK.07/2016 about Alternative Institution Settle Monitoring in Financial Service Sector.

d. Standard policy of IDR in Financial Service Institution.

Consumer protection which provided by FSA includes loss prevention, consumer complaint services, and legal defense. Regarding to the loss prevention for consumers, FSA has the authority to take consumers and the public loss preventation, which includes:

1. provide information and education to the public on the characteristics of the financial services sector, services, and its products;

2. ask the financial services institution to stop its activities if the activity has the potential to harm the community; and

3. other actions deemed necessary in accordance with statutory provisions in the financial services sector.

For the implementation of the complaints service carried out by FSA such as giving facilitation of the settlement of consumer complaints that are disadvantaged by the financial services institution. In an effort to prevent violations of the provisions in FSA Law, there are several instruments for the service of consumer complaints on violations committed by business actors, which include:

1. prepare adequate tools for consumer complaints services that have been disadvantaged by actors in financial services institutions;

2. create a mechanism for consumers complaints who have been harmed by actors in the financial services institution; and

3. facilitate the resolution of complaints of consumers who have been harmed by actors in the financial services institution in accordance with the laws and regulations in the financial services sector.

Financial Service Authority has another authority beside of carry out loss prevention and consumer complaint services. There are two authorities which are included in the defense of law for consumers, there are:

1. order or take certain actions to financial service sector business actors to settle complaints from consumers who have been harmed by financial service sector business actors;

2. file a lawsuit:

a. to recover the assets from the party who caused the loss, whether it is under the control of the party causing the loss and is under the control of another bad party; and/or

b. to obtain compensation from parties who caused losses to consumers and/or financial services institutions as a result of violations of laws and regulations in the financial services sector. 
Referring to the authority scope of the FSA especially in providing legal protection for consumers and the community as described above, so the authority of FSA in the consumer protection legal system is not limited not only to facilitate consumer protection that accommodates and becomes a mediating institution, but also to become an institution that takes sides to consumers in form of legal defense activities. In addition, the forms of protection carried out by the FSA include the protection to prevent violations and the restoration of consumer rights in the event of losses suffered by consumers.

The efforts that FSA can do toward a accruement of complaint are very wide, ranging from receiving complaints, facilitating the resolution of complaints, examining and investigating financial services institutions, perpetrators, and/or financial services supporters, filing a lawsuit for returning the assets of the injured party, filing a claim for compensation until set the administrative penalty and order or take certain actions to the financial services institutions to resolve complaints from consumers who have suffered by that financial services institutions.

\subsection{Obstacles Faced by the Financial Services Authority in Handling the Existence of Illegal Fintech Companies}

As an independent institution, FSA has a vision and mission that is always strived for to be realized in the community. The vision is to become a trustworthy financial services industry supervisory institution, protect the interests of consumers and the community, and be able to turn the financial services industry into a pillar of the national economy that is globally competitive and can advance public welfare. While the mission of FSA are:

1. Realizing the implementation of all activities in the financial services sector in an orderly, fair, transparent and accountable manner;

2. Creating a financial system that grows in a sustainable and stable manner;

3. Protect the interests of consumers and society.

Efforts to realize the missions above and its role in super visioning and handling financial services, especially illegal fintech's are not without obstacles. The existence of these constraints basically cannot be separated from the existence of inhibiting factors so that the objective of the FSA's existence cannot be achieved as expected. Broadly speaking, the obstacles faced by FSA in dealing with the existence of illegal fintech can be distinguished between internal and external constraints.

The internal constraints are the existed obstacles originating from within the FSA itself, such as:

1. Limited human resources. The scope of financial services that must be regulated and supervised by the FSA is very much. FSA must be able to cover all of its tasks and roles in both bank financial institutions, non-bank financial institutions, and financing institutions while the number of human resources in FSA is still limited. The imbalance between workload with the amount of human resources will certainly affect the smoothness and success of the task at hand.

2. Infrastructure facilities that are still implanted with Bank Indonesia. The existence of FSA which is relatively new, resulting in the lack of available infrastructure and facilities, both in the form of offices or other facility infrastructure which will ultimately affect the comfort and fluency of staff in carrying out their duties.

3. Lack of socialization to the public about the existence of fintech companies. This obstacle is inseparable from the still limited human resources and infrastructure facilities as mentioned above. The extent of the area and the many layers of society that must be given socialization are also factors not yet maximized this activity. Lack 
of socialization to the public results in the level of literacy about the financial industry, especially regarding fintech, which is very minimal so that it will be very risky for fraud that will harm the public.

4. Difficulties in coordination. There are 13 institution who are included as supervisors to supervise fintech companies especially for illegal fintech in investment alert security, there are:
a. Financial Service Authority
b. Ministry of Trade
c. Coordinating Board of Capital Investment
d. Ministry of Cooperatives and Small Business
e. Ministry of Communication and Information
f. Attorney General's Office
g. Police Headquarters
h. Bank Indonesia
i. Center for Financial Transaction Reporting and Analysis
j. Ministry of Religion
k. Ministry of Home Affairs
1. Ministry of Education and Culture
m. Ministry of Research Technology and Higher Education.

The high number of agencies and institutions involved in the investment alert security is a special factor in coordinating. This is happen due to its own task and activities which must be carried out. This difficulties in coordinating will affect the effectiveness to tackle illegal fintech companies. However, at the end, FSA will handle by making a coordination to all members of the investment alert security, for example in the case of illegal fintech closure, it will also be disseminated in the media so public knows and can get the information related to the existence of illegal fintech.

In addition to the internal constraints above, the handling of the existence of illegal fintech companies is also constrained due to external factors. Some of the external constraints are:

1. A low level of public understanding (literacy) of the financial services industry and financial products/services. The lack of public literacy in the financial services industry including fintech may be due to the lack of socialization carried out by FSA. Financial literacy is a knowledge, skills, and beliefs, which influence attitudes and behaviors to improve the quality of decision making and financial management in order to prosper. Based on the survey results of the 2016 by FSA and released in early 2017 related to the level of financial literacy, information is obtained if the level of financial literacy in the public is still low and uneven.

The survey results state that Indonesia's financial literacy index is only $29.66 \%$. This result is still far below the financial literacy index of Malaysia which reached $65 \%$, especially Singapore which has reached the index of $98 \%$. In addition to the low literacy index, its distribution is also not evenly distributed where four of the five provinces with the highest literacy rates are found on Java.7 Seeing the connection between literacy and the decision making above, the delivery of information through the socialization program needs to be improved.

2. The regulation and policy of consumer protection in financial sector are not integrated yet. Differences in the characteristics of the financial services sector require an integrated regulation and supervision including consumer protection aspects. This is a challenge for FSA which has the function of making integrated arrangements and 
supervision in the financial services sector. In addition, FSA synergizes regulations and/or financial consumer protection policies for financial service institutions that provide payment system services that are also supervised by Bank Indonesia. With integrated regulations and policies it will become clearer and better guarantee legal certainty.

3. Uncertainty of the company's legality status that have been known in the public. The certainty of the legal fintech company can actually be known and accessed by the public on the FSA official website, there is information about the legal and illegal companies. Sometimes the problems that occur in the financial industry are not entirely caused by the company but also by consumers' mistakes. Therefore, if the public wants to borrow through fintech, public should know beforehand whether the company has been registered or licensed by FSA or not. The public should be more careful with the increasingly massive financial product offering activities carried out by companies that are not registered or licensed by FSA that have the potential to harm the public.

4. The inhibiting factors that cause fintech companies to not register and take fintech company licenses to FSA are:
a. lack of literacy
b. the licensing process takes long time (6 months)
c. must be a legal entity
d. capital administrative requirements that are too high.

Referred to Article 4 FSA Law Number 77 / POJK.01 / 2016, providers in the form of limited liability companies must have paid up capital of at least IDR 1,000,000,000.00 (one billion rupiahs) when registering and at least IDR 2,500,000,000.00 (two billion five hundred million rupiahs) when applying for a permit. The amount of capital that must be deposited is the reason that caused illegal fintech's to be reluctant to register and arrange permits to FSA. In addition, the registration procedure to obtain a permit is not easy and must be gradual, if the fintech company does not meet the fintech requirements, it cannot be accepted or rejected.

5. Victims of illegal fintech companies do not report. There are many communities with various considerations who do not report violations committed by illegal fintech companies. In the absence of reports from the public, FSA has difficulty to find out and crack down on illegal fintech companies that are detrimental to the community. Therefore, the participation of the community or victims from fintech companies is needed to report to FSA with a very easy reporting system, which can contact FSA call center and can also come directly to FSA office.

The obstacles above, both the obstacles from FSA's own internal and external will ultimately determine the optimization of FSA's success in handling the existence and activity of illegal fintech companies. This means that in an effort to deal with the existence of illegal fintech companies, it cannot be done partially or incidentally. These efforts must be carried out comprehensively and continuously as well as the existence of synergy by involving all stakeholders involved in the operation of the illegal fintech company. 


\section{Conclusion and Recommendation}

Based on the results of research and discussion as described above, it can be concluded, that:

1. The Financial Services Authority (FSA) has the tasks and functions to carry out a system of regulation and supervision that are integrated to all activities in the financial services sectors. To support these tasks and functions, FSA has the authority to draw up regulations and set operational policies in order to effectively carry out their duties. In the field of law enforcement, FSA also has the authority to set administrative penalty for companies that violate the provisions of the legislation. Regarding protection to the public, FSA has been given the authority to take preventive measures and consumer complaints services and to conduct legal defense for the interests of consumers.

2. Obstacles that faced by the Financial Services Authority (FSA) in handling the existence of illegal fintech companies include both the internal and external of FSA. Internal obstacles are caused by limited human resources, insufficient infrastructure, lack of intensity of socialization, and difficulties in coordination among investment task security. While external obstacles are caused by a low level of understanding (literacy) of the community on the financial services industry and financial products/services, regulations and consumer protection policies in the financial sector that have not been integrated. In addition, other obstacles in the form of uncertainty about the legality status of the company known to the public and the unwillingness of victims from illegal fintech companies did not report. In the absence of reports from victims, the FSA has difficulty to find out and crack down on illegal fintech companies that are detrimental to the community

Based on the results of the discussion and conclusions as stated above, it is recommended to:

1. To the Financial Services Authority (FSA) to further enhance the education program to the community through socialization so the level of public literacy is better and it will be precise and safe in determining and utilizing the fintech financial industry.

2. The consumer community is expected to increase their literacy on fintech and be careful and vigilant in selecting fintech companies, ensuring that the fintech companies are licensed or registered by FSA.

3. The financial services business actor or fintech company is expected to take the registration and permit to FSA as a business legality so its existence is declared valid and at the same time as an effort to provide legal protection to consumers or the public

\section{References}

[1] Iman, Nofie. 2016. Financial Technology dan Lembaga Keuangan. Yogyakarta: Gathering Mitra Linkage Bank Syariah Mandiri.

[2] Soekanto, Soerjono dan Sri Mamudji. 1986. Penelitian Hukum Normatif Suatu Tinjauan Singkat. Jakarta: CV. Rajawali.

[3] Sutedi, Andrian. 2014. Aspek Hukum Otoritas Jasa Keuangan, Jakarta:Raih Asa Sukses.

[4] Bachri, Bachtiar S. 2010. Meyakinkan Validitas Data Melalui Triangulasi pada Penelitian Kualitatif (Convincing Data Validity through Triangulation on Qualitative Research), Education Technology Journal, Volume 10, Number 1, April 2010. 
[5] Saksonova, Svetlana dan Irina Kuzmina-Merlin. "Fintech as Financial Innovation - The Possibilities and Problems of Implementation", dalam European Research Studies Journal Volume XX, Issue 3A, 2017.

[6] Anggraeni, Rina. 635 Fintech Ilegal Tercatat OJK, 231 Sudah Ditutup. https://ekbis. sindonews.com > bursa finansial. Diakses tanggal 15 Pebruari 2019 pukul 15.40 WIB.

[7] Anonim. https://www.awantunai.com/single-post/2017/07/17/Tidak-Ada-Lagi-HambatanAkses-Finansial-Fintech-Dapat-Menolong-Anda-1. Akses Tanggal 26 januari 2019, pukul 20.00 WIB.

[8] Tim Jurnalistik Legalscope, Perkembangan Fintech di Indonesia. http://www. legalscope.id/perkembangan-fintech-di-indonesia. Diakses tanggal 24 Januari 2019, pukul 15.05 WIB. 